\title{
New and interesting freshwater diatoms (Bacillariophyceae) from a biodiver- sity hotspot area in China
}

\author{
Yan LiU ${ }^{1}$, John Patrick KocioleK ${ }^{2}$, Quanxi WANG ${ }^{3}$, Lixin $\mathrm{Li}^{4} \&$ Yawen FAN ${ }^{*}$ \\ ${ }^{1}$ College of Life Science and Technology, Harbin Normal University, Harbin, 150025, P. R. China; *Corresponding \\ author e-mail:Yawen Fan:fanyw@163.com \\ ${ }^{2}$ Museum of Natural History and Department of Ecology and Evolutionary Biology, University of Colorado, \\ Boulder, CO 80309, U. S. A. Orcid ID 0000-0001-9824-7164 \\ ${ }^{3}$ College of Life and Environment Science, Shanghai Normal University, Shanghai, 200234, China \\ ${ }^{4}$ College of Resource and Environment Engineering, Heilongjiang Institute of Science and Technology, Harbin \\ 150027, China
}

\begin{abstract}
Biodiversity "hotspot" areas have been shown to possess unique diatom floras. During our diatom studies of some of these types of areas in China, samples were collected from Hainan and Guangdong Provinces, and four species from 4 different genera are proposed as new to science based on LM and SEM observations. These new taxa are Eunotia dinghunsis Liu \& Kociolek, sp. nov., Brachysira subirawanae Kociolek \& Liu, sp. nov., Microcostatus muscus Liu \& Kociolek, sp. nov. and Iconella sanyatangum Liu \& Kociolek, sp. nov. In addition, a species known previously only from Java and Sumatra, Pinnularia rivularis Hustedt, was observed, and herein we provide LM and the first SEM observations of this species.
\end{abstract}

Key words: Bacillariophyceae, new species, diatom, biodiversity hotspots, China

\section{INTRODUCTION}

Biodiversity "hotspots" have been identified as those areas featuring exceptional concentrations of endemic species and experiencing exceptional loss of habitat (MYER et al. 2000). Twenty-five hotspots have been identified from around the world, amounting to just 1.4 percent of the land surface of the planet, yet supporting nearly 60 percent of the world's plant, bird, mammal, reptile, and amphibian species (MYER et al. 2000). Diatom research has occurred from just a few of these hotspots, for example in the regions in and around Amazonia, resulting in the description of many new taxa and documentation of tremendous biodiversity (e.g., Metzeltin \& Lange-Bertalot 1998, 2002, 2007; RUMricH et al. 2000).

Two areas within China are among the 25 worldwide hotspots. These two Chinese sites include "Mountains of Southwest China" and the "Indo-Chinese subregion". The latter area covers part of southern and western Yunnan Province, coastal lowlands of southern Guangxi and Guangdong provinces, as well as several offshore islands, such as Hainan Island in China (MYER et al. 2000). To begin to develop a better understanding of the diatom biodiversity of these hotspot areas in China, a research initiative was developed to understand the freshwater diatom flora of the "Indo-Chinese subregion", including places such as Hainan island, and the southern sections of Guangdong, Guangxi and Yunnan Provinces. Past efforts yielded several species new to science (LIU et al. 2014a, b; LIU et al. 2016; LIU et al. 2018a; JiANG et al. 2018; CHENG et al. 2018), suggesting this area may have a unique diatom flora.

Hainan island is a tropical island, located in the South China Sea. It is the second largest island of China. It was separated from the Leizhou Peninsula by volcanism in middle of Pleistocene. It is home to numerous organisms and many endemic species; 630 plants, 2 mammal and 2 birds were reported as endemic to this island (CARPENTER 2001). Many new species were reported from Hainan, including vascular plants (HuANG et al. 2012), ferns (Dong 2010), invertebrates (LIU \& Li 2009; ZHAO et al. 2013) and vertebrates (ZHAO 1997), among others. But our understanding of the diatom flora of Hainan is far from comprehensive. Reports of diatoms from Hainan are rare. Primary research of this area was done in late 1980's and 1990's, resulting in the description of five new diatom taxa. The new taxa include: Gomphonema turris var. reimeri (ZHANG \& CAI 1988), Eunotia hainanensis (ZHANG \& 
QI 1993), Fragilaria hainanensis Zhang in ZHANG \& QI (1994), Fragilaria leptostuaron var. hainanensis Zhang in ZHANG \& QI (1994), and Fragilaria lapponica var. lanceolata Zhang in ZHANG \& QI (1994) (non Fragilaria lapponica var. lanceolata Hustedt). These new species have never been reported outside of China, but they may be unknown to most researchers since the literatures on diatoms from this region were in the Chinese language. Making comparisons of these taxa more difficult is the fact that all of the type materials for them have been lost for the historical reasons. Most taxa found in these studies are considered as cosmopolitan species in the compilation study, Diatom Flora of China (QI 1995; QI \& Li 2004; LI \& QI 2010; SHI 2004, 2013).

Guangdong Province is located in the southern portion of the Chinese mainland, just opposite (North of) Hainan island. The tropical and subtropical monsoonal climate in the region make this province warm and moist. Studies on the freshwater diatoms of this province are rare, with the only studies being by LI et al. (2009) and LiU et al. (2013), but neither identified new species.

In 2012, 60 collections were taken from Hainan island and the southern portion of Guangdong province. In this paper, 4 species are proposed as new to science, and we offer formal descriptions of these taxa based on LM and SEM observations. In addition, we have encountered a previously-described species of Pinnularia known only from Java and Sumatra. We present LM and the first SEM observations of this species described by Friedrich Hustedt.

\section{Material ANd Methods}

Samples were collected from Hainan Province and the southern part of Guangdong Province in February, 2012. Sixty samples were collected and field-fixed with $4 \%$ formalin, while $\mathrm{pH}$, temperature and conductivity were determined for each sampling locality with a KL-009III Pen-based high-precision $\mathrm{pH}$ meter and a DDB-11A portable digital conductivity meter. Sample information and measured environmental parameters are provided for the four samples used to describe the new taxa herein in Table 1.

Samples were boiled in concentrated nitric acid for an hour and washed, and alternatively settled for 24 hours and washed with distilled water 7 times in the laboratory. Cleaned materials were preserved in distilled water in $10 \mathrm{ml}$ glass tubes. For LM observations, cleaned material was air-dried onto coverslips which were subsequently mounted in Naphrax on microscope slides, then examined with an Olympus BX 51 microscope, DIC, at the University of Colorado, and Zeiss Imager A2 with DIC, at Harbin Normal University. For SEM observations, cleaned material was air-dried onto copper stubs, coated with gold/palladium, and observed with a Hitachi S-4800 field emission electron microscope (Harbin Normal University, voltage 15kv), FEI Quanta 200FEG field emission electronic microscope (Harbin Institute of Technology) or a JEOL 6380-LA scanning electronic microscope (Shanghai Normal University). Material and slides are housed at the Key Laboratory of Biodiversity of Aquatic Organisms, Harbin Normal University and at the Diatom Lab at the University of Colorado, Boulder. Diatom images were compiled with Photoshop 7.0.

\section{Results AND Discussion}

\section{Eunotia dinghunsis Liu et Kociolek sp. nov. (Figs 1-10) Description}

LM observations: Valves distinctly dorsiventral, lunate, slightly swollen towards the apices, ends of the valves obtusely rounded. Ventral margin concave to almost straight. Dorsal margin convex, parallel to the ventral margin. Valve length 94-200 $\mu \mathrm{m}$, width 7.0-10.5 $\mu \mathrm{m}$. Striae almost parallel in the middle of the valve, slightly radiate close to the ends, $12-13 / 10 \mu \mathrm{m}$ in the middle, denser towards the ends, $14-15 / 10 \mu \mathrm{m}$. Spines are present along both margins, 5-7/ $10 \mu \mathrm{m}$. Distal raphe endings extend markedly onto the valve face.

SEM observations: Externally, valve face flat, connecting with the ventral mantle at a right angle. Distal raphe endings are clearly visible, extending onto the valve face; the central raphe endings are curved to the opposite side of the valve (Fig. 6) on the mantle. Uniseriate striae consist of small round areolae (Fig. 7). Acute spines are present along the entire valve margin (Figs $5,7,8)$. Mantle and girdle bands contain open areolae (Fig. 8). Internally, internal areolar openings are simple, unoccluded (Fig. 10). Distal raphe endings terminate in well-developed helictoglossae (Figs 9-10). The valve has a single rimoportula at each apex, located at the tip of the valve. The rimoportulae have distinct, lip-like outer openings (Figs 9-10).

Holotype: HANU! Slide no. THGZ2012023 (Harbin Normal University, Harbin.

China). Fig. 2 is of a specimen from the holotype slide. Isotype: COLO! Kociolek Collection (University of Colorado, Boulder, U.S.A.). Accession Number 9054. Type locality: Dinghu Mountain in Guangzhou Province, China. Collected at 9th Feb. 2012, by Liu Y. et Li L.X. Habitat: Epiphyton to filamentous algae, in a small stream under the waterfall.

Etymology: Named for the type locality.

Remarks: This large species has the raphe located mostly on the mantle, then running onto the valve face. Rimoportulae are present at both apices, and spines outline the valve along the valve margin. Together these features have been used to recognize the genus Desmogonium Ehrenberg. Recognition of Desmogonium as a genus separate from Eunotia Ehrenberg has varied, with some authors considering it to be a synonym or subgenus of Eunotia (e.g. Hustedt 1933, 1949; MetzeLtin \& LANGE-BERTALOT 1998), or accepted as a separate genus (Metzeltin \& Lange-Bertalot 2007). The features used to distinguish between Desmogonium and Eunotia are the spines on both margins and the rimoportulae on both apices (Patrick \& Reimer 1966; Metzeltin \& 
LANGE-BERTALOT 1998). However, some have argued that these two characters cannot be the diagnostic features of Desmogonium. For example, while most "typical" Eunotia species have only one rimoportula per valve, located at one apex, several Eunotia species also have two rimoportulae, one located at each apex, such as in E. densistriata Torgan (Torgan \& Becker 1997), E. charliereimeri Edlund et Brant (Edlund \& Brant 2010) and E. corsica Lange-Bertalot et Roland Schmidt (LANGE-BERTALOT et al. 2011). In these cases, the former two species do not have spines, while the latter species has prominent polar spines (LANGE-BerTaLOT et al. 2011). More generally within the Eunotiaceae Kützing (KüTZING 1844), the number of rimoportulae differs among genera, with some having no rimoportulae, such is the case in Semiorbis Patrick (PATRICK \& Reimer 1966) and Colliculoamphora Williams et Reid (Williams \& REID 2006b). Other genera have a single rimoportula at each apex, such as in Amphorotia Williams et Reid (Williams \& ReID 2006a) and Eunophora Vyverman, Sabbe et Mann (VYVERMAN et al. 1998), and valves with one rimoportula, such as in most Eunotia species and Actinella Lewis (LewIs 1864), in which there is one rimoportula at either the headpole or footpole (Round et al. 1990). More recently, Eunotioforma Kociolek et Burliga (KocioleK \& Burliga 2013) was shown to have several rimoportulae per valve (up to 8).

Spines are a relatively common feature in Eunotia, and several species may have various arrangements of spines along the margin or only at the apex, for example in $E$. pseudopectinalis Hustedt, E. soleirolii (Kützing) Rabenhorst, E. denticulate (Brébisson \& Kützing) Rabenhorst, and E. flexuosa (Brébisson) Kützing (Lange-Bertalot et al. 2011; Pavlov \& Levkov 2013). These observations suggest the presence of spines might not be a useful feature to distinguish Desmogonium from Eunotia.

The number of taxa assigned to Desmogonium is 15 (as listed in DiatomBase, Kociolek et al. 2020), and described as "very common in the tropics, in strongly acid water" (PATRICK \& Reimer 1966). Several species of the genus have already been transferred to Eunotia, such as Desmogonium rabenhorstianum, Desmogonium rabenhorstianum var. elongatum and Desmogonium transfugum (Metzeltin et Lange-Bertalot) Metzeltin et Lange-Bertalot. The latter species was initially described as a Eunotia then transferred back to Desmogonium (MetZeltin \& LANGE-Bertalot 2007).

Our new species presented here is quite similar in outline to some Desmogonium species, but most of the Desmogonium species have apices that are swollen, as in D. guianaense Ehrenberg, D. rabenhorstianum and $D$. transfugum or triangulate ends, such as kurzianum (Grunow) Hustedt (SснмiDt 1911) and D. ossiculum Metzeltin et Lange-Bertalot (Metzeltin \& LANGE-BERTALOT 2007). Valve outline easily differentiates these taxa from $E$. dinghunsis sp. nov.

Other Eunotia species that are similar to E. dinghunsis sp. nov. include E. corsica found from Corsica, 


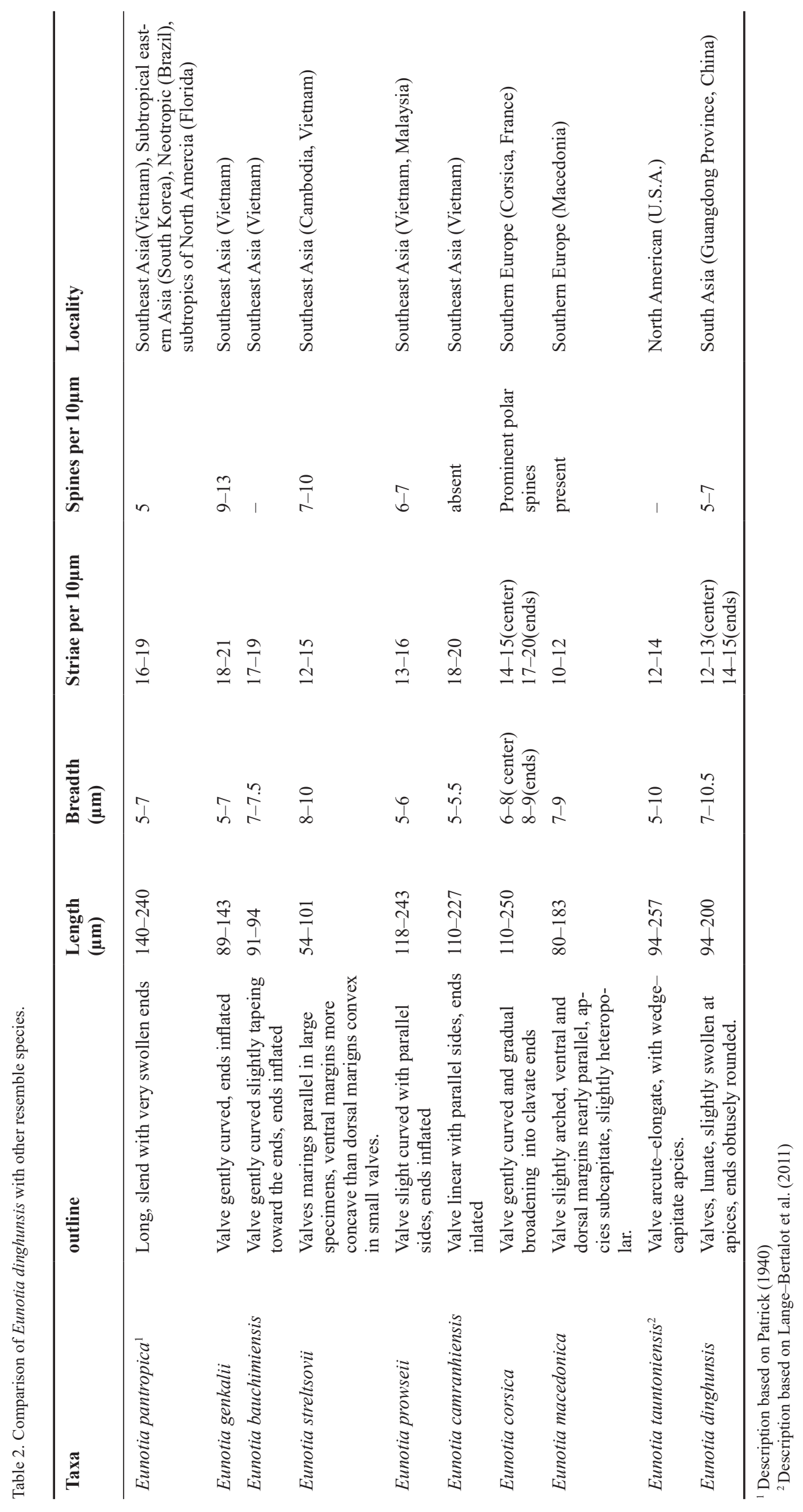




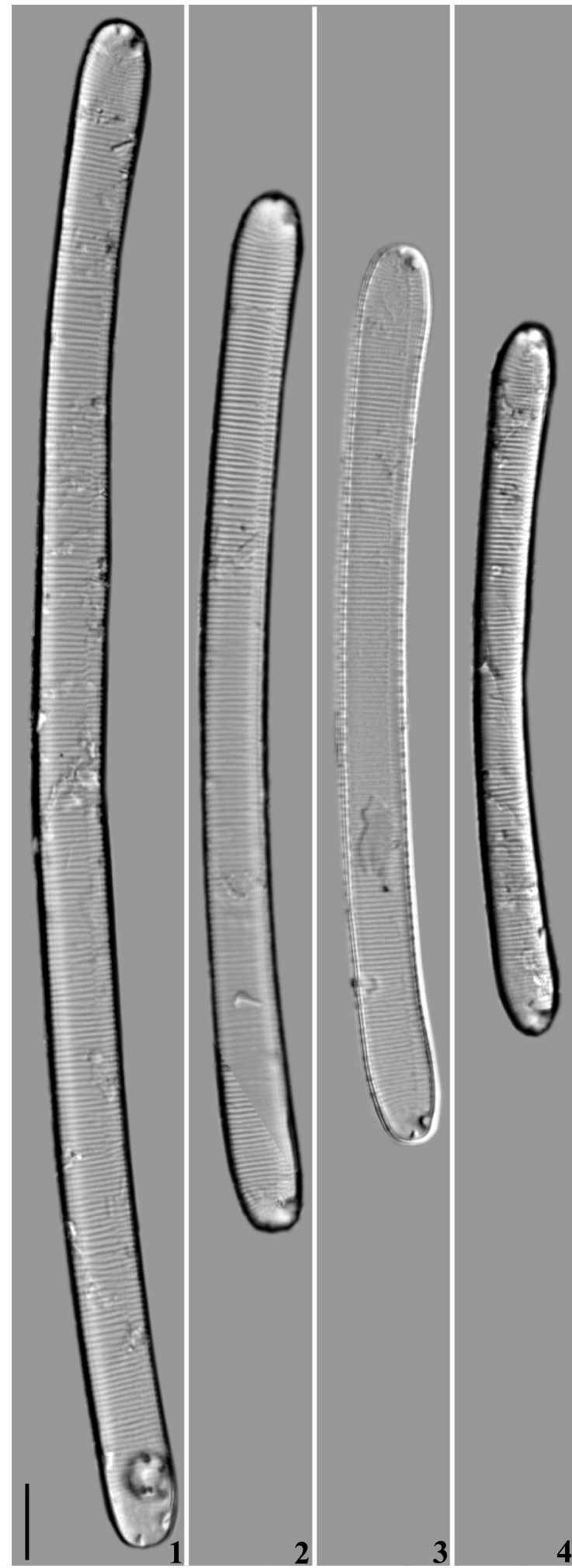

Figs 1-4. Eunotia dinghunsis Liu et Kociolek sp. nov., LM pictures, showing size range of the species. Fig. 2 is of the holotype. Scale bar $10 \mu \mathrm{m}$.

France, which was reported to co-occur with numerous Eunotia and acidobiontic diatoms (LANGE-BERTALOT et al. 2011), E. macedonica Lange-Bertalot, Pavlov et Levkov was described from Southern Europe also. $E$. tauntoniensis Hustedt et Patrick was reported from U.S.A.
E. genkalii Glushchenko, Kulikovskiy et Kociolek, E. bauchimiensis Glushchenko, Kulikovskiy et Kociolek, E. streltsovii Glushchenko, Kulikovskiy et Kociolek, E. prowseii Glushchenko, Kulikovskiy et Kociolek, E. camranhiensis Glushchenko, Kulikovskiy et Kociolek and E. pantropica, all share the similar morphology with our new species and were found nearby in southeast Asia (GLusHCHENKo et al. 2018). The differences between these species and our new species are valve outline, breadth, striae density, and presence or absence of spines, and these differences are detailed in Table 2.

A further review of morphological features and / or new molecular data may indicate that Desmogonium should be segregated from Eunotia. If that is the case our new species might be better placed in Desmogonium. However, currently we include our new species in Eunotia, and await revisionary work on Desmogonium with analyses based on morphological and molecular approaches to resolve the relationship of Desmogonium to Eunotia, and in the context of the entire Eunotiaceae.

Brachysira subirawanae Kociolek et Liu sp. nov. (Figs 11-26)

\section{Description}

LM observations: Valve lanceolate-clavate, apices protracted with narrowly rostrate ends. Length 23.0-38.7 $\mu \mathrm{m}$, width 5.5-6.9 $\mu \mathrm{m}$. Axial area linear, very narrow, slightly expand in the middle of the valve, forming a small elongated elliptic central area. Striae slightly radiate, composed of 2-4 areolae, areolae irregularly spaced transversally, producing longitudinal hyaline undulations on the valve surface.

SEM observations: Externally, raphe straight, proximal raphe endings straight (Fig. 21). Distal raphe endings straight, combined with a groove between the last areola at each side (Figs 22, 23). Ribs are present along both sides of the raphe in some specimens (Figs 20, 22). Striae are uniseriate, $25-26 / 10 \mu \mathrm{m}$ in the center, $27-28 / 10 \mu \mathrm{m}$ at the apices. Areolae are transversally elongate, irregularly-sized and spaced (Figs 19, 20). A single row of slit-like areolae is present on the valve mantle (Figs 21-23). Internally, each stria is occluded by a single hymenate covering (Figs 24-26). Proximal raphe endings are slightly curved toward the same side (Fig. 26). Helictoglossae slightly raise at the end of the raphe (Figs 24-25).

Holotype: HANU! Slide no. THHN2012015 (Harbin Normal University, Harbin, China). Fig. 11 is of a specimen from the holotype slide.

Isotype: COLO! Kociolek Collection (University of Colorado, Boulder, U.S.A.). Accession Number 9047. Type locality: Orchid valley in Yalong Bay Forest Park, Hainan Province. Collected at $14^{\text {th }}$ February 2012, by Liu Y. et Li L.X.

Habitat: Epiphyton on leaves and stones, in a small flowing stream.

Etymology: Named for resembling the species Brachysira irawanae (Podzorski et Håkansson) 


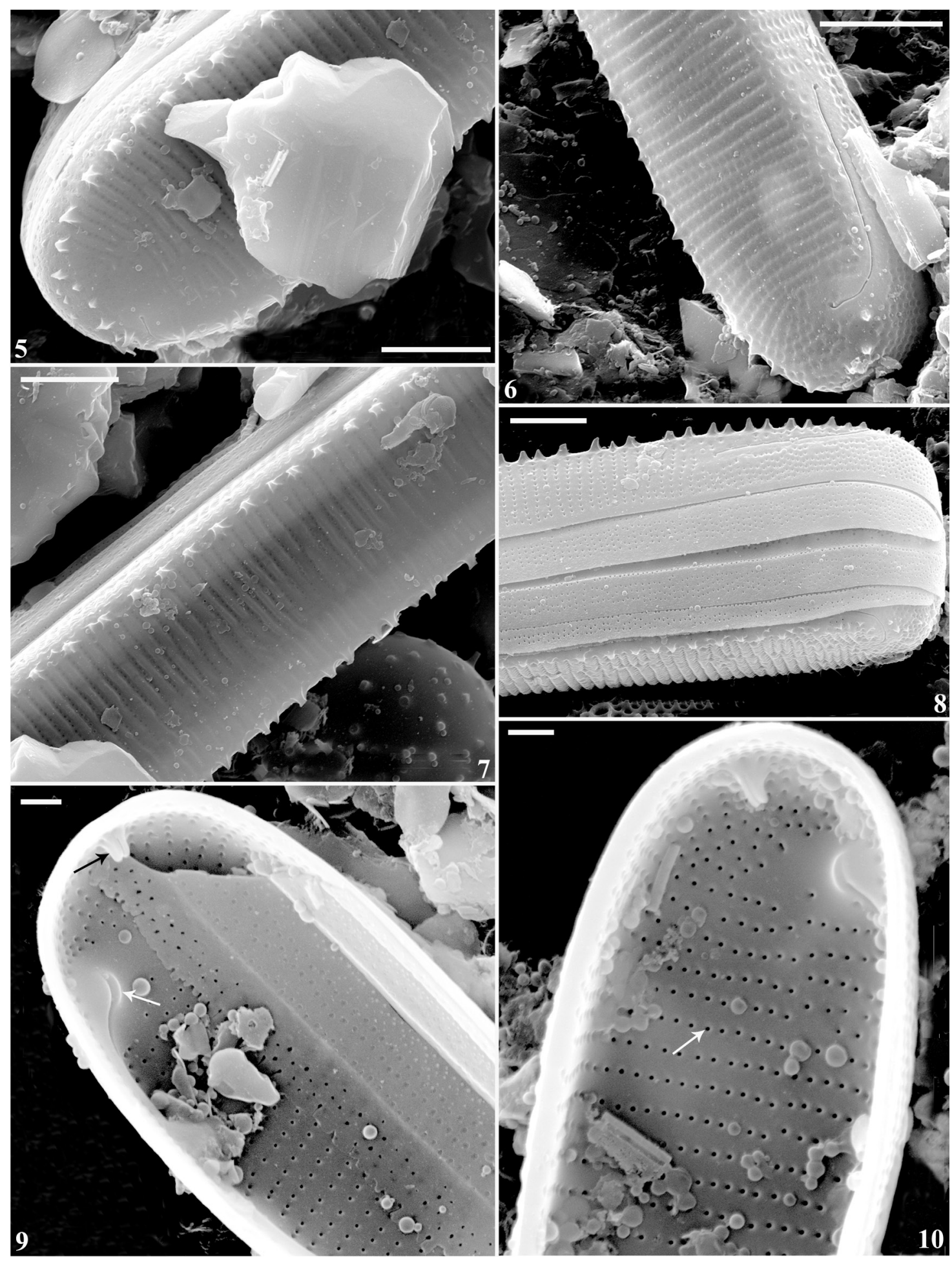

Figs 5-10. Eunotia dinghunsis Liu et Kociolek sp. nov. SEM pictures: (5-8) external view, (5) apex of the valve showing the spines, (6) apex of the valve, showing the raphe, (7) middle of the valve, showing the spines and striae, (8) girdle view of the valve apex, showing the open band with multi-rows of poroides; (9-10) internal view of the two apices of one valve, (9) apex of the valve, showing helictoglossa (white arrow) and rimportula (black arrow), (10) apex of the valve, showing the internal opening of areolae (white arrow). Scale bar $5 \mu \mathrm{m}(5-8), 1 \mu \mathrm{m}(9-10)$.

Lange-Bertalot et Podzorski.

Remarks: Brachysira Kützing is characterized by having linear to lanceolate valves with round to protracted apices, longitudinal undulations formed by areolae, ribs present along the raphe and valvemantle junction, and elongate areolae on the mantle (Vouilloud et al. 2014). This genus has a group of species with gomphonemoid symmetry (LANGEBertalot \& Moser 1994: Taf 29-32). Among this group, Brachysira gomphonemoides (Maillard) Lange-Bertalot et Moser, B. seippii Lange-Bertalot et Moser, B. maillaridii Lange-Bertalot et Moser, and B. insolita (Manuskriptnamen) Lange-Bertalot et Moser are easily separated from our new species 


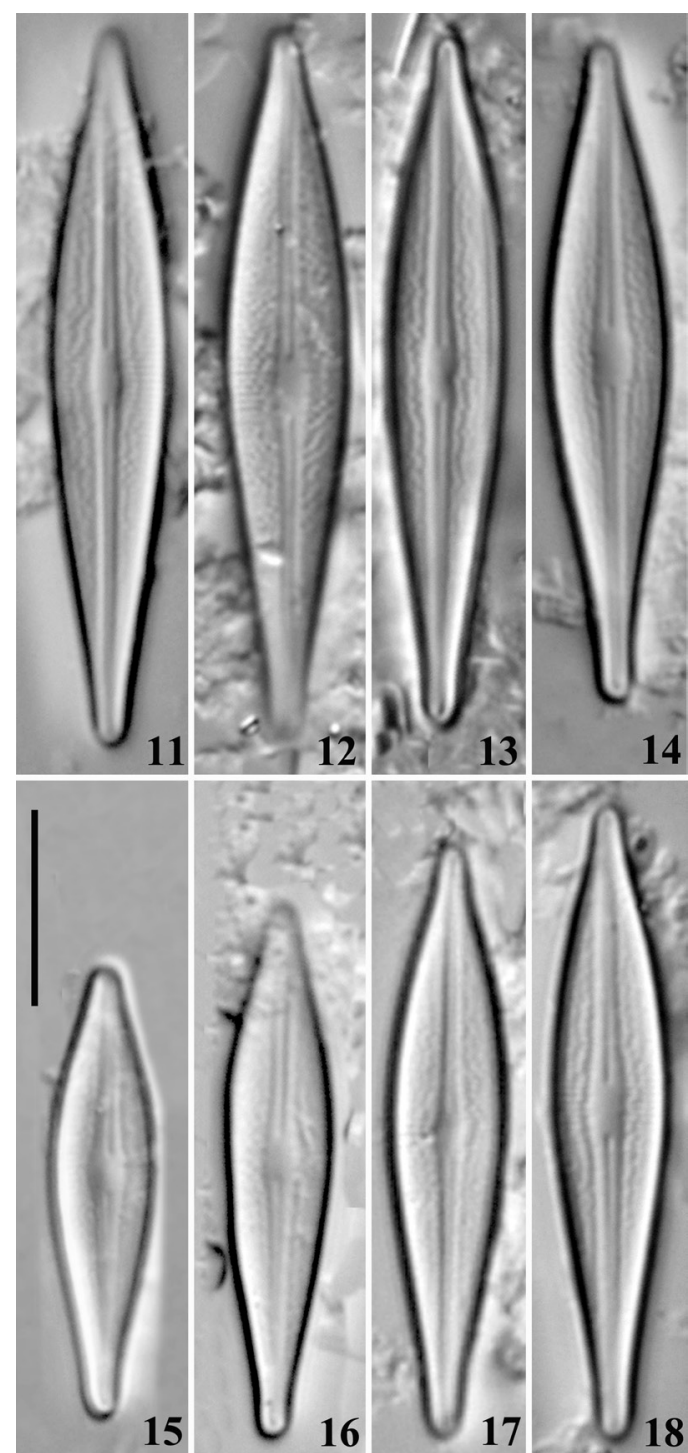

Figs 11-18. Brachysira subirawanae Kociolek et Liu sp. nov., LM pictures, showing size range of the species. Fig. 11 is of the holotype. Scale bar $10 \mu \mathrm{m}$.

by outline; $B$. microclava Lange-Bertalot et Moser is smaller and has papillae on valve surface; $B$. blancheana (Maillard) Lange-Bertalot et Moser has capitate apices; $B$. archibaldii Coste et Ricard, B. archibaldii var. crassistriata Lange-Bertalot and $B$. procera Lange-Bertalot et Moser all lack protracted ends.

The species most similar in morphology to $B$. subirawanae, sp. nov. are $B$. irawanoides Lange-Bertalot et Moser and B. irawanae (Podzorski et Håkansson) Lange-Bertalot et Podzorski. B.irawanae was described as having wedge-shaped ends, and it is longer and narrower (length $15-50 \mu \mathrm{m}$, breadth $4.5-6.5 \mu \mathrm{m}$ ) than $B$. subirawanae sp. nov. B. irawanoides was described as having blunt, rounded ends, and it has valves that are smaller (length 19-30 $\mu \mathrm{m}$, breadth 4.2-4.8 $\mu \mathrm{m}$ ) (LANGe-Bertalot \& Moser 1994) than B. subirawanae sp. nov. Our new species has protracted to rostrate ends, valves with higher length to breadth ratio than the former two species. Another difference among these three taxa is the density of the striae, with $B$. irawanae and $B$. irawanoides having denser striae, up to 30-32 per $10 \mu \mathrm{m}$, as compared with $B$. subirawanae sp. nov. which has 25-26/10 $\mu \mathrm{m}$.

\section{Microcostatus muscus Liu et Kociolek sp. nov. (Figs} 27-45)

\section{Description}

LM observations: Frustule small. Valve linear to lanceolate, with small capitate apices. Length 10.0-15.7 $\mu \mathrm{m}$, width 3.0-3.5 $\mu \mathrm{m}$. Axial area narrow, central area small. Striae not visible under LM.

SEM observations: Externally, two lyre-shaped depressions are present along the prominent sternum parallel to the axial area (Fig. 38). The depressions are wider in the middle of the valve and become narrower, discontinuous and punctate towards the apices. Depressions contain small slit-like costae (Fig. 39), 4-6 per $1 \mu \mathrm{m}$. Axial area narrow, linear. Valve face with thick silicification, areolae are occluded externally. Proximal raphe endings straight (Fig. 39), distal raphe endings curved in same directions onto the mantle (Fig.38). Internally, raphe straight, proximal raphe endings slightly expanded, small and round (Fig. 43). Areolae are unoccluded, round or elliptic, 2-3 per stria. Helictoglossa are slightly raised at the end of valve (Figs 44-45).

An incomplete valve is shown in figure 42. In this valve the striae are composed of slit-like areolae, one per striae. A row of pores on the mantle appears to be a continuation of the striae.

Holotype: HANU! Slide no. THGZ2012030 (Harbin Normal University, Harbin, China). Fig. 27 is of a specimen from the holotype slide.

Isotype: COLO! Kociolek Collection (University of Colorado, Boulder, U.S.A.). Accession Number 9032.

Type locality: Dinghu Mountains, Guangdong Province. Collected on 9 February, 2012, by Liu Y. et Li L.X.

Habitat: Living in the mosses on the wet wall.

Etymology: This species is named for it being found living amongst moss on a wet wall.

Remarks: Microcostatus Johansen et Sray (JoHANSEN \& SRAY 1998) is a small genus, with 22 taxa listed in KocioleK et al. (2020). The most distinctive characters for the genus are that the valves are small, with two longitudinal depressions along the central sternum and lacking a conopeum (VAN DE VIJVER et al. 2010; STANEKTARKOWSKA et al. 2016). More recently, however, a conopeum and pseudoconopeum have been reported from species in this genus (TAYLOR et al. 2010; VAN DE ViJVER et al. 2013; Li et al. 2016).

The characters used to differentiate the species within this genus are the outline of valve, striae and areolar pattern on the depressions and valves, areolae on the conopeum or pseudoconopum if they are present, and areolae internal openings. Our new species is very distinctive compared with other known species in this 


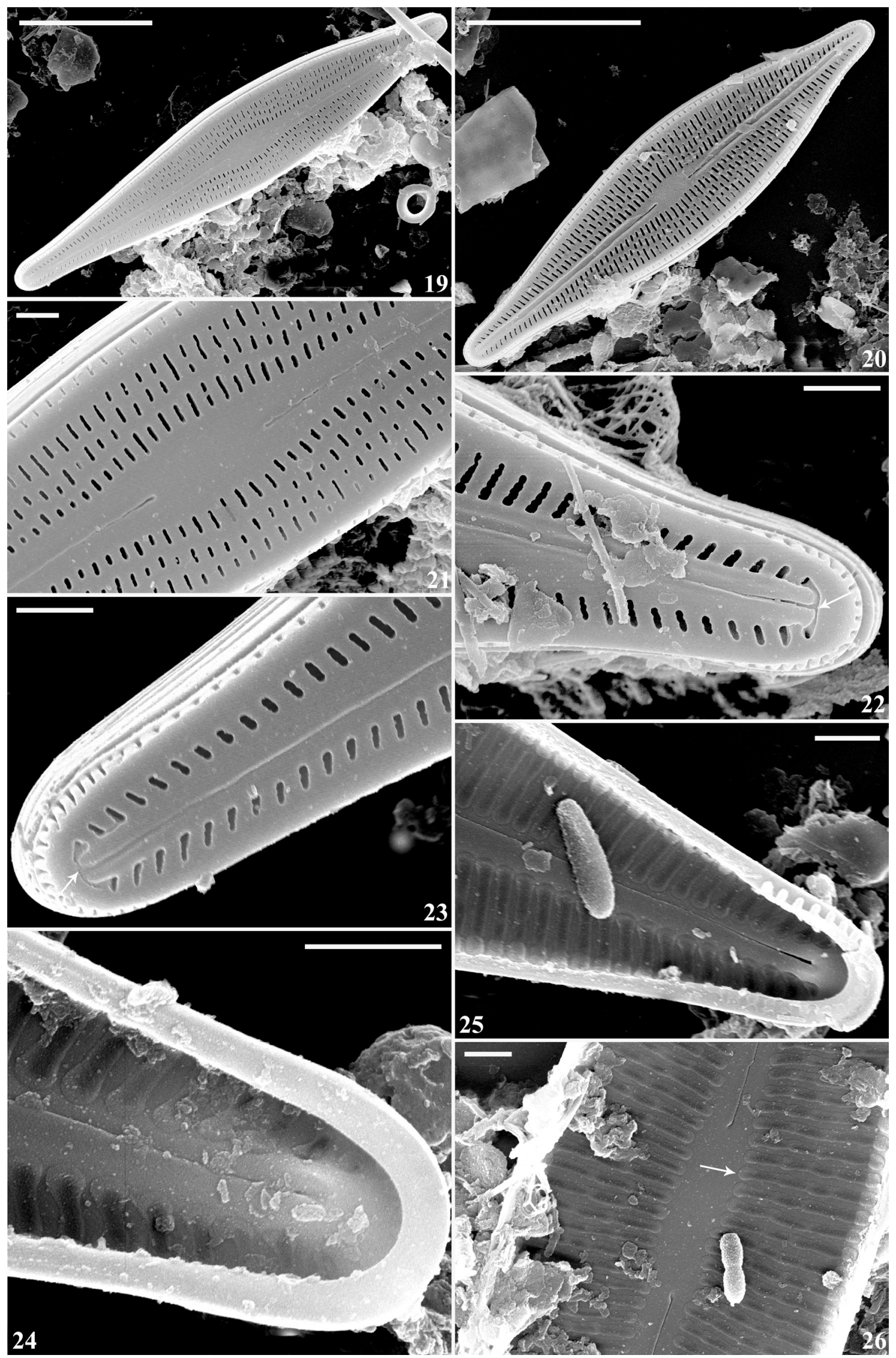

Figs 19-26. Brachysira subirawanae Kociolek et Liu sp. nov., SEM pictures: (19-23) external view, (19-20) whole valve, (21) central area, showing the straight proximal raphe endings and elongated areolae, (22) headpole of the valve, showing the terminal raphe endings and groove between the last two areolae (white arrow), (23) footpole of the valve, showing the terminal raphe endings, groove between the last two areolae (white arrow) and the slit-like areoale on the mantle; (24-26) internal view, (24) footpole of the valve, showing the helictoglossa, (25)

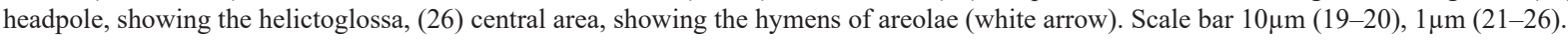




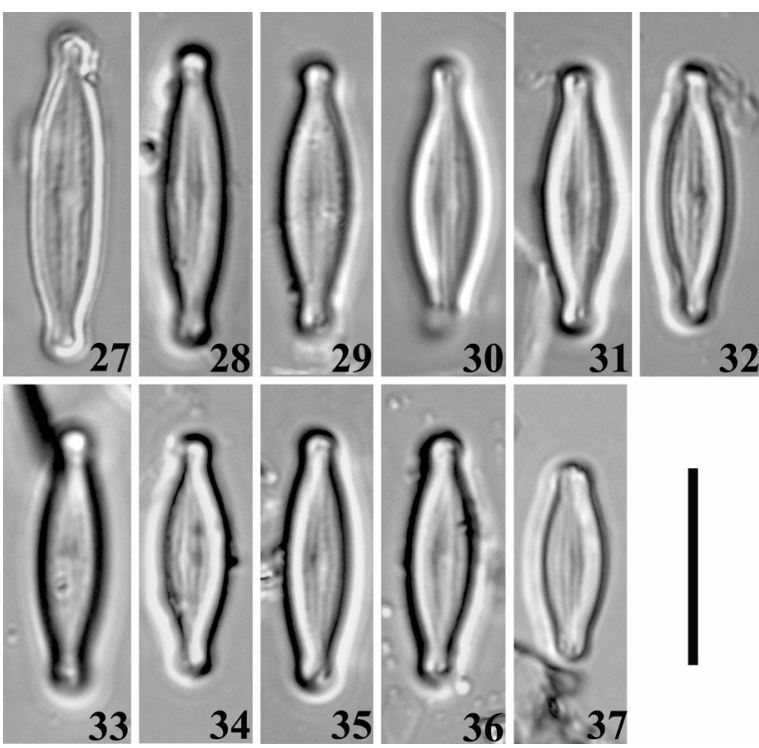

Figs 27-37. Microcostatus muscus Liu et Kociolek sp. nov. LM pictures, showing the size range of the species. Fig. 27 is of the holotype. Scale bar $10 \mu \mathrm{m}$.

genus based on its outline, discontinuous depressions, and small slit-like costae within the depressions.

\section{Pinnularia rivularis Hustedt (Figs 46-59)}

Schmidt 1934, pl. 392: 1; Simonsen 1987, plate 255: 3-5.

LM observations: Valves large, linear, slightly expanded in the center and at the ends, with nearly undulate sides, ends bluntly rounded. Length 75.8-83.6 $\mu \mathrm{m}$, width 10.6-11.5 $\mu \mathrm{m}$. Axial area linear, occupying 1/5 $-1 / 4$ width of the valve. Central area large, rhombic, extended to the valve margin. On one side of the central area, next to the end of the striae, 2-3 thickened areas are visible (Figs 53, 57, 58). Raphe lateral, with small, rounded proximal raphe ends. Terminal fissures on the valve, large, "?" shaped. Striae radiate in the middle, convergent towards the ends.

SEM observations: Externally, the raphe is straight, with proximal raphe ends small and round, slightly curved toward one side of the valve (Fig. 54). Distal raphe endings are large, "?"-shaped, barely extending onto the mantle (Figs 55-56). Striae composed of 4-5 rows of areolae with silicified external opening. Internally, raphe continuous, without an intermissio. On one side of the central area there are 2-3 round depressions (Fig. 57). At each distal end, a small helictoglossa is present (Fig. 59). Areolae are unoccluded (Fig. 58).

Remarks: This species differs from other Pinnularia species by its outline and round, internal depressions around the central area. Hustedt published this new species from Java and Sumatra (SCHMIDT 1934; HustedT 1938), with the remark "until now found in the $\mathrm{pH}$ range of 6.5-7.8, further information is not possible for the time being" (HuSTEDT 1935, 1938). SimONSEN (1987) presented three valves from Hustedt's type. This species has been poorly illustrated since it was reported. HoHn \& HeLlerman (1963) recorded one valve from La Vase River, Canada, without a detailed description, and PATRICK \& REIMER (1966) listed the species under "Name of taxa reported from the U.S. (fresh water) which could not be verified by a specimen from a public herbarium" suggesting the record by Hohn and Hellermann is suspect. Our specimens were also found from a tropical area (sample number THHN2012015, see Table 1), near the type locality, and the morphological features found in the Chinese specimens fit Hustedt's description of Pinnularia rivularis. This is the first publication of SEM observations of this taxon.

Iconella sanyatangum Liu et Kociolek sp. nov. (Figs 60-79)

Description

LM observations: Frustules are rectangular in girdle view (Figs 65-67). Valves are long, slender and straight. The two sides of the valve are almost parallel the entire length of the valve, without a median constriction; towards the apices valves become narrower and form bluntlyrounded, but not protracted ends. Length 150-207 $\mu \mathrm{m}$, breadth $6.8-8.8 \mu \mathrm{m}$. The external valve surface consists of thickened and evenly-spaced transverse ribs across the valve. A very narrow median region is present in the middle of the valve. Alar canals $30-40$ in $100 \mu \mathrm{m}$. Striae $17-19$ in $10 \mu \mathrm{m}$.

SEM observations: Externally, the raphe is situated between two relatively wide ridges on top of the keel. Raphe ridges thicken around the apex of the valve at the point where the distal raphe fissures curve down onto and back along the mantle forming a fish hook design (Fig. 70). The fenestrae and alar canals are very short, such that the keel almost rests on the valve surface (Figs 68, 73). The ends of the valve are depressed and smooth (Fig. 68). Otherwise ribs are flat and wide, supported by thicken siliceous ridges across the whole valve (Figs 69, 71). Some ribs terminate in the middle of the valve, others are combined and become a single rib at the middle of the valve (Fig. 69). Two or three rows of siliceous granules are difficult to observe between the ribs. There is a narrow median area between the two sides of siliceous granules (Fig. 71). The siliceous granules cover the areolae externally. Internally, areolae are unoccluded (Fig. 77). The striae are composed of two to three rows of areolae (Fig. 77). Alar canals are narrow, about 2-3 $\mu \mathrm{m}$ wide.

In girdle view mantle ribs differ from valve ribs, as they appear wider, with regular or irregular sides (Figs $70,72)$. The ribs are almost connected. Fenestral openings are similar to other parts of the valve, however they are not as obvious as those at the apex since the valve are depressed here. Copulae are open laterally.

Valves with rimmed areolae at apex but no siliceous granules were observed (Fig. 75). The rimmed areolae can be found in both valve view and girdle view. And granules were also observed between ribs, which the sides were not silicified (Fig. 74). But comparing the 


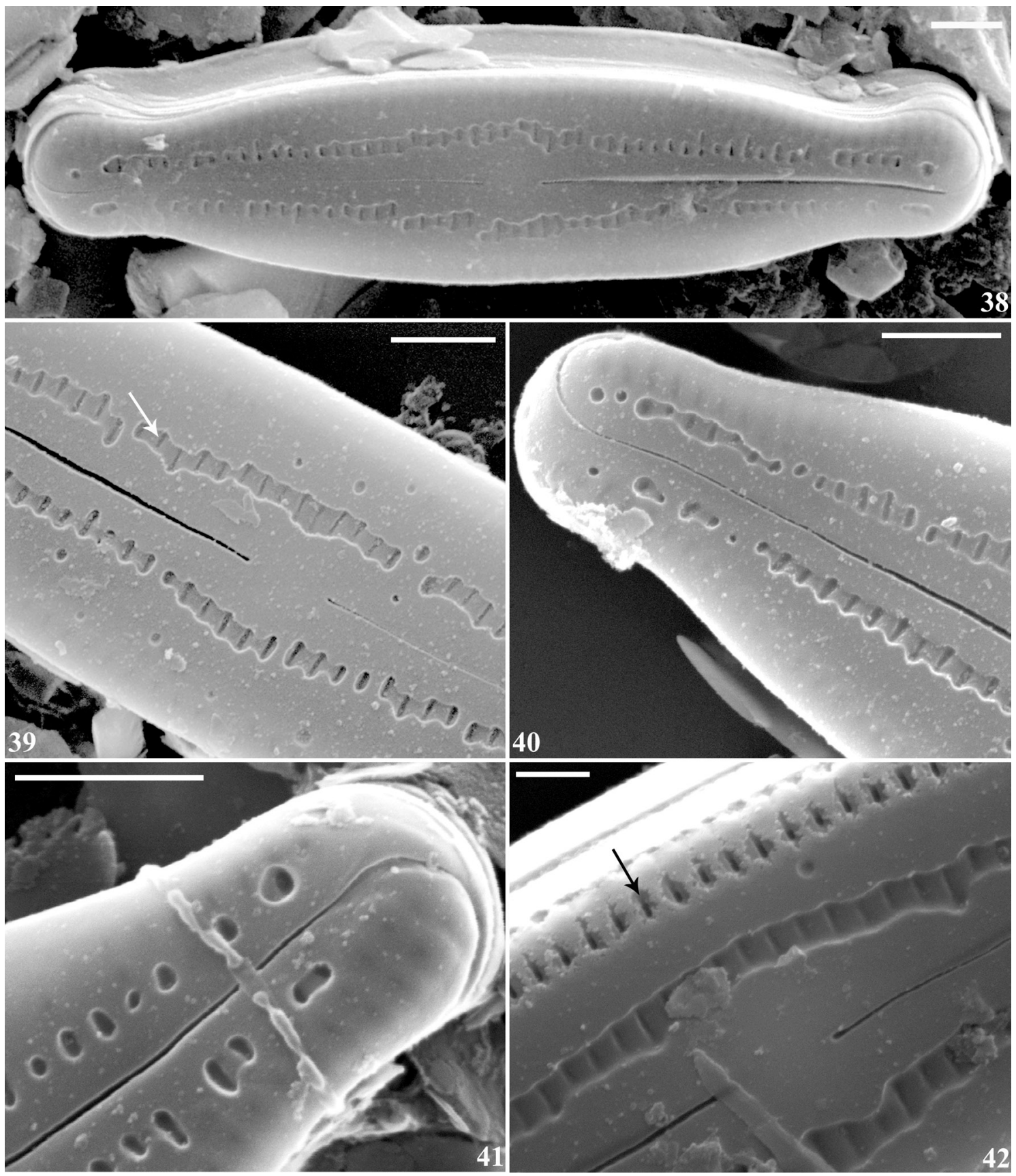

Figs 38-42. Microcostatus muscus Liu et Kociolek sp. nov., SEM external view: (38) whole valve, showing the depression along the central sternum; (39) central area, showing the slit-like coste in the depressions (white arrow), and the straight proximal raphe endings; (40-41) apex of the valve, showing the terminal raphe ending; (42) uncompleted valve, showing the areolae opening (black arrow). Scale bar 1 $\mu \mathrm{m}(38-41)$, $0.5 \mu \mathrm{m}(42)$.

structure of valve areolae and mantle ribs with other valves, we considered these valves to be incompletely formed valve.

Holotype: HANU! Slide no. THGZ2012017 (Harbin Normal University, Harbin, China). Fig. 62 is of a specimen from the holotype slide.

Isotype: COLO! Kociolek Collection (University of Colorado, Boulder, U.S.A.). Accession Number 9049.

Type locality: Sanyatang valley in Guangdong Province, China. Subaerial, attached to filamentous algae on decayed wood. Collected on Feb. 7, 2012, by Liu Y. et Li L.X.
Habitat: Epiphyton on filament algae in the stream. Etymology: Named for the type locality.

Remarks: Based on the recent classification scheme for Surirellaceae, our new species would belong to Iconella Jurilj, which was resurrected by RUCK et al. (2016) and expanded to include the Robustae group of Surirella Turpin and Campylodiscus (Ehrenberg) Ehrenberg et Kützing, as well as the entire genus Stenopterobia Brébisson et Van Heurck. The morphological features for identifying Iconella are "raphe canal rises above the valve face and 


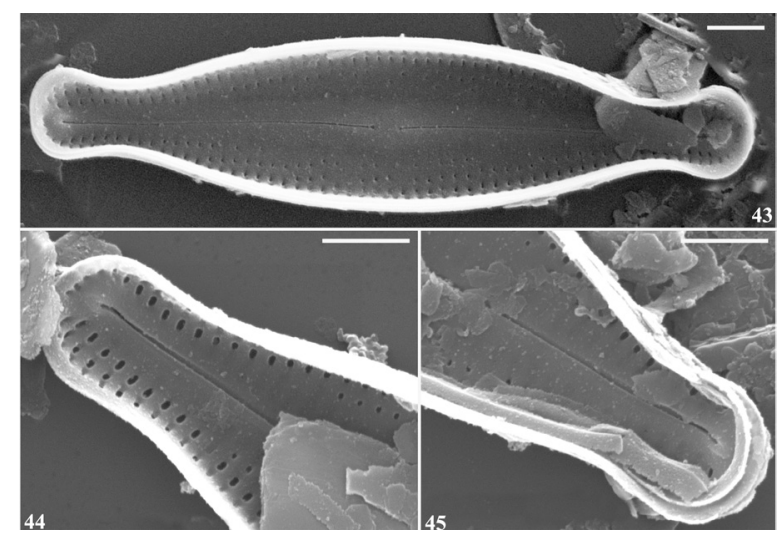

Figs 43-45. Microcostatus muscus Liu et Kociolek sp. nov., SEM internal view: (43) whole valve; (44) apex of the valve, showing the helictoglossa and areolae openings; (45) apex of the valve, showing the helictoglossa. Scal bar $1 \mu \mathrm{m}$.

mantle and has alar canals with fenestral openings occluded by fenestral bars with internally rimmed pores" (JAHN et al. 2017). According to its long, slender valve with bluntly round apices, this new species shares some features with the straight species in previously-recognized genus Stenopterobia. Iconella sanyatangum sp. nov. most closely resembles Stenopterobia schweickerdtii (Cholnoky) Brassac, Ludwig et Torgan (Brassac et al. 2003) which was originally described as Surirella schweickerdtii Cholnoky (CHOLNOKY 1954). BRASSAC et al. (2003) did not study the type material. We cannot conclude whether the specimens studied by them are indeed the same as the original species, but the specimens illustrated in BRASSAC et al. (2003) are more similar to our new species in terms of size, alar canal and striae densities, and valve structure. Mantle ribs in Iconella sanyatangum are wider and the fenestral openings are obvious near the apex of the valve only; this feature helps to distinguish it from the specimens in Brazil reported as Stenopterobia schweickerdtii.

Some of the valve features found in S. sanyatangum appear unique in this group, such as the transverse ribs across the valve, which were supported by the silica ridges, lack of median area, and granules present on the valve surface.

\section{Conclusions}

Although there has been a tremendous amount of work done to describe the freshwater diatoms of China (BI \& LIANG 1994; Br et al. 2001), many areas lack even initial surveys, let alone the development of a comprehensive flora. Recent diatom research in China yielded the description of many new species from many area of China, with more than 75 new species reported since 2017, e.g. Li et al. (2019), Liu B. et al. (2018a, b; 2019), Liu Q. et al. (2017; 2019a, b), Liu Y. et al. (2018a, b, 2020a, b, c), Luo et al. (2018), You et al. (2017; 2019a, b) Yu et

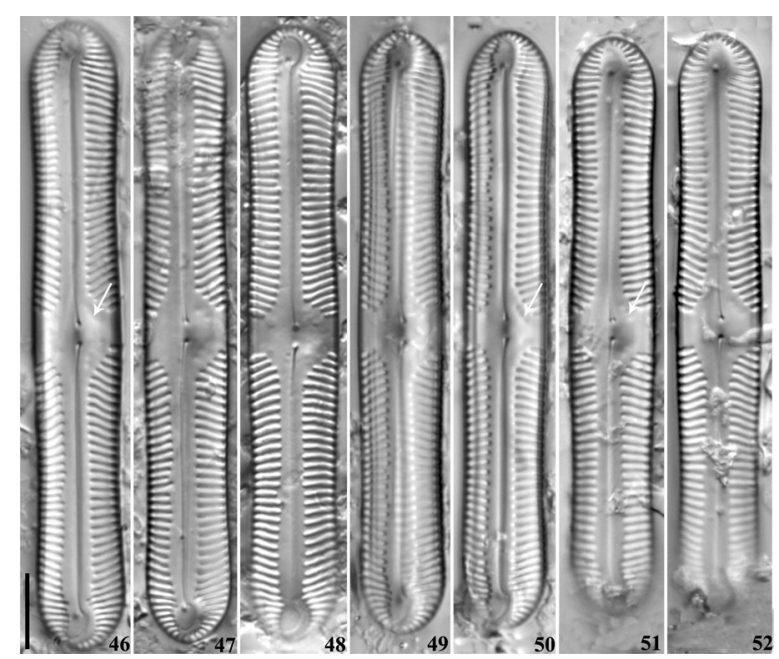

Figs 46-52. Pinnularia rivularis Hustedt., LM pictures, showing the size range of the species, white arrows show the stigma. Scale bar $10 \mu \mathrm{m}$.

al. (2018, 2019), YANG et al. (2019) and ZHANG et al. (2018a, b; 2019). The discovery of these new species from Hainan island and South of Guangdong Province indicate these places may have high biodiversity of diatom. Further research of "Indo-Chinese subregion" biodiversity hotspot will likely yield additional interesting results to help us to understand the overall number and taxonomic breadth of the diatom flora in this region.

\section{REFERENCES}

Bi, L.J. \& Liang, J.J. (1994): The history of Phycology in China. Beijing: Science Press.

BI, L.J.; Hu, Z.Y. \& LIU, G.X. (2001): The review on early literature of freshwater algae systematics in China and the chronology. - pp. 262-272, Wuhan, Wuhan Press.

Brassac, N.M.; Torgan, L. C. \& Ludwig, T. A. (2003): Transfer of Surirella schweickerdtii to the genus Stenopterobia.-Diatom Research 18: 185-190.

Burliga, A.L.; Kociolek, J.P.; Salomoni, S.E. \& Figueiredo, D. (2013): A new genus and species in the diatom family Eunotiaceae Kützing (Bacillariophyceae) from the Amazonian hydrographic region, Brazil. -Phytotaxa 79: 47-57.

CARPenter, C. (2001): Hainan Island monsoon rain forests (IM0169) [Internet]. World Wide Fund for Nature. Available from: http://www.worldwildlife.org/.

Cheng, Y.; Liu Y.; Kociolek, J.P.; You, Q.M. \& Fan, Y.W. (2018): A new species of Gomphosinica (Bacillariophyta) from Lugu Lake, Yunnan Province, SW China. -Phytotaxa 348: 118-124.

Снolnoky, B. J. (1954): Diatomeen und einige andere Algen aus dem "de Hoek"-Reservat in Nord-Transvaal. -Botanisku Notiser 3: 269-296.

Dong, S.Y. (2010): A new species of Dryopteris (Dryopteridaceae) from Hainan Island, China. -Botanical Studies 51: 537-542.

EdLund, M. B. \& BRANT, L.A. (2010): Eunotia charliereimeri, A new Eunotia species (Bacillariophyceae) with amphoroid frustule symmetry. - Proceedings of the Academy 


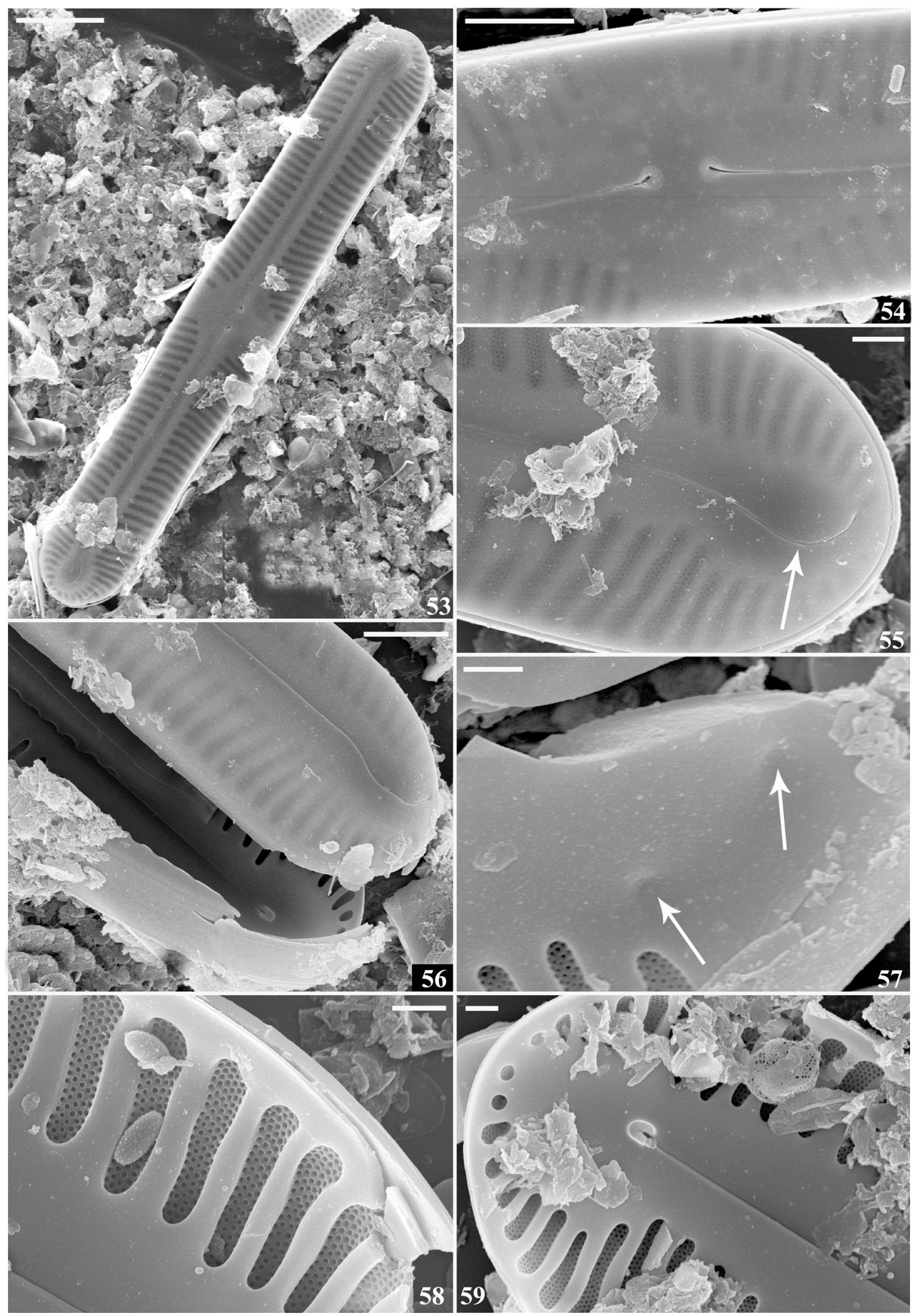

Figs 53-59. Pinnularia rivularis Hustedt., SEM pictures: (53-56) external view, (53) whole valve, (54) central area, showing the central pores, (55) apex of the valve, showing the "? "shaped terminal raphe ending located at the valve (white arrow), (56) apex of the valve, showing the terminal rahe ending and helictoglosssa; (57-59) internal view, (57) central area, showing the depressions (white arrows), (58) showing the areolae and interstriae, (59) apex of the valve, showing the helictoglossa. Scale bar $10 \mu \mathrm{m}(53), 5 \mu \mathrm{m}(54,56), 2 \mu \mathrm{m}(62), 1 \mu \mathrm{m}(55,57-59)$. 


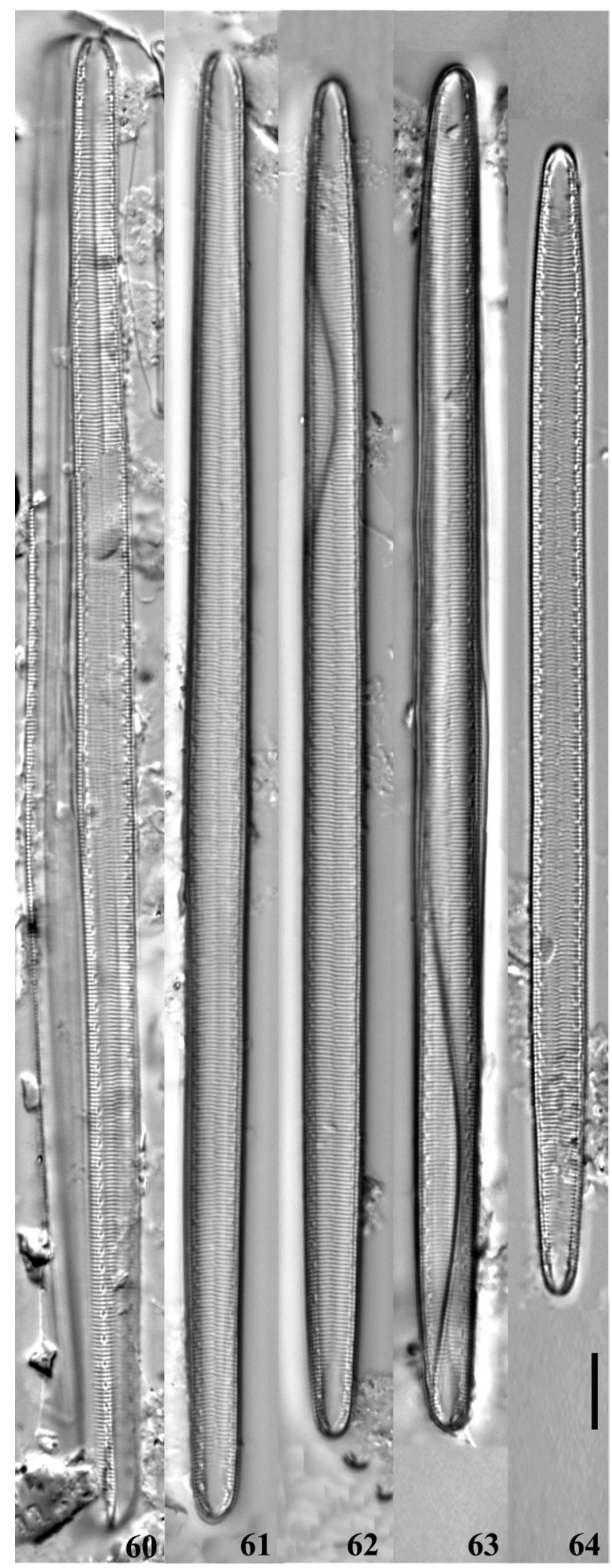

Figs 60-64. Iconella sanyatangum Liu et Kociolek sp. nov., LM pictures, valve view. Fig. 62 is of the holotype, showing the siza range of species. Scale bar $10 \mu \mathrm{m}$

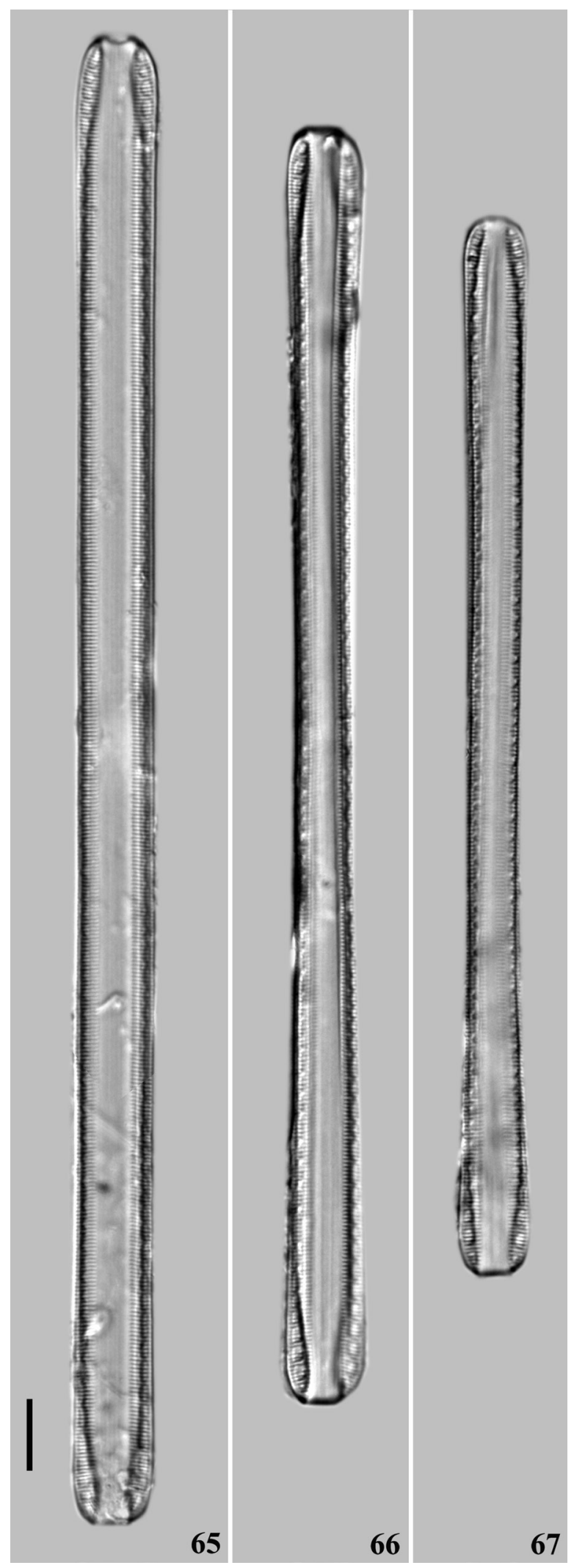

Figures 65-67. Iconella sanyatangum Liu et Kociolek sp. nov., LM pictures, girdle view. Scale bar $10 \mu \mathrm{m}$ 


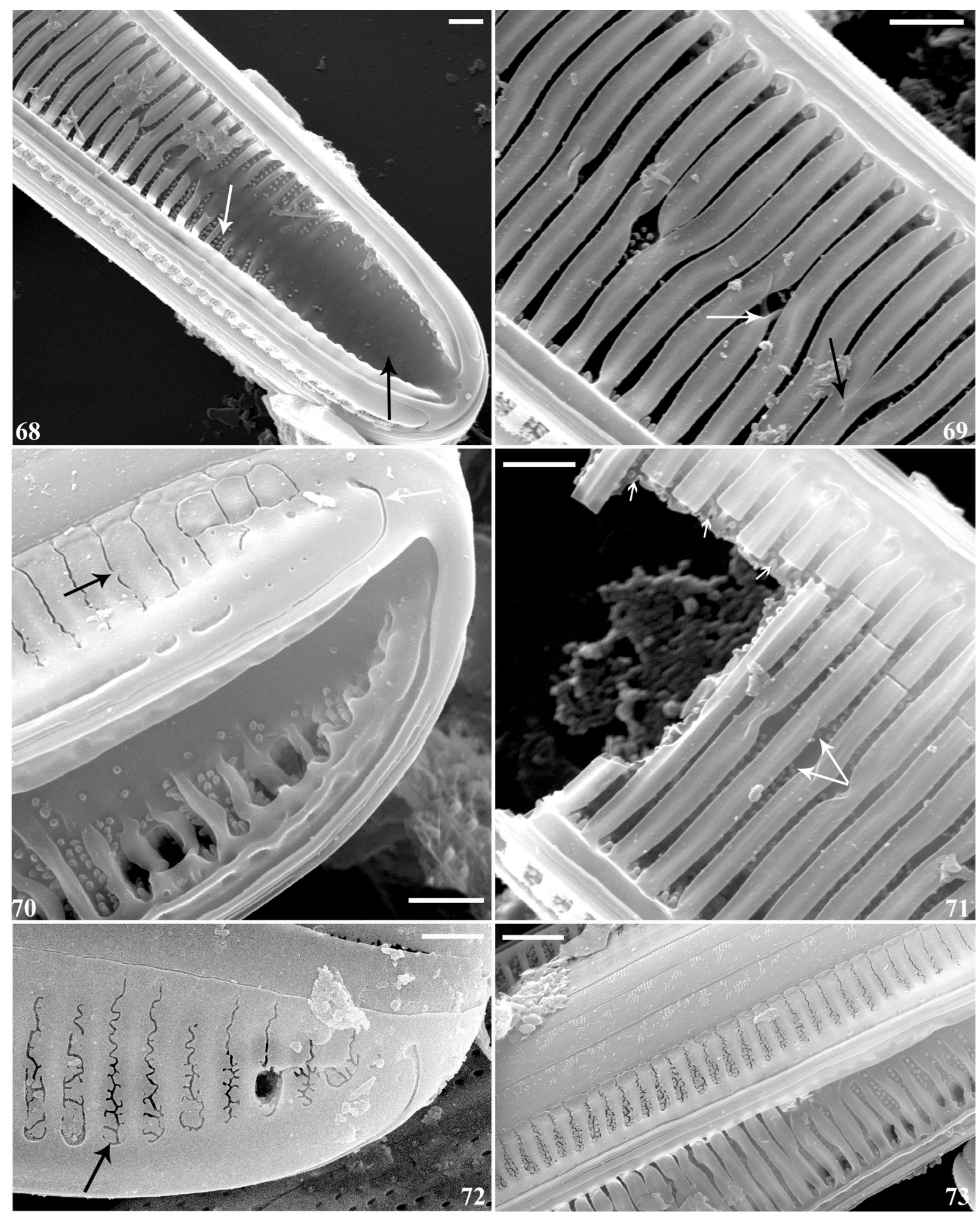

Figs 68-73. Iconella sanyatangum Liu et Kociolek sp. nov., SEM pictures, external view: (68) apex of the valve, showing the terminal raphe endings, the capped areolae (white arrow) and smooth depression (black arrow); (69) surface of the valve, showing the ribs across the whole valve. Some ribs stopped at the middle of the valve (white arrow), some ribs combined and become one rib in the middle (black arrow); (70) girdle view of the valve apex, showing the terminal raphe fissure (white arrow) and wide mantle ribs with regular sides (black arrow); (71) a broken valve, showing the median area (large white arrows) and granules covered the areolae (small white arrows); (72) girdle view of the valve apex, showing the wide mantle ribs with irregular sides (black arrow); (73) girdle view of valves showing numerous opening bands. Scale bar $1 \mu \mathrm{m}$. 

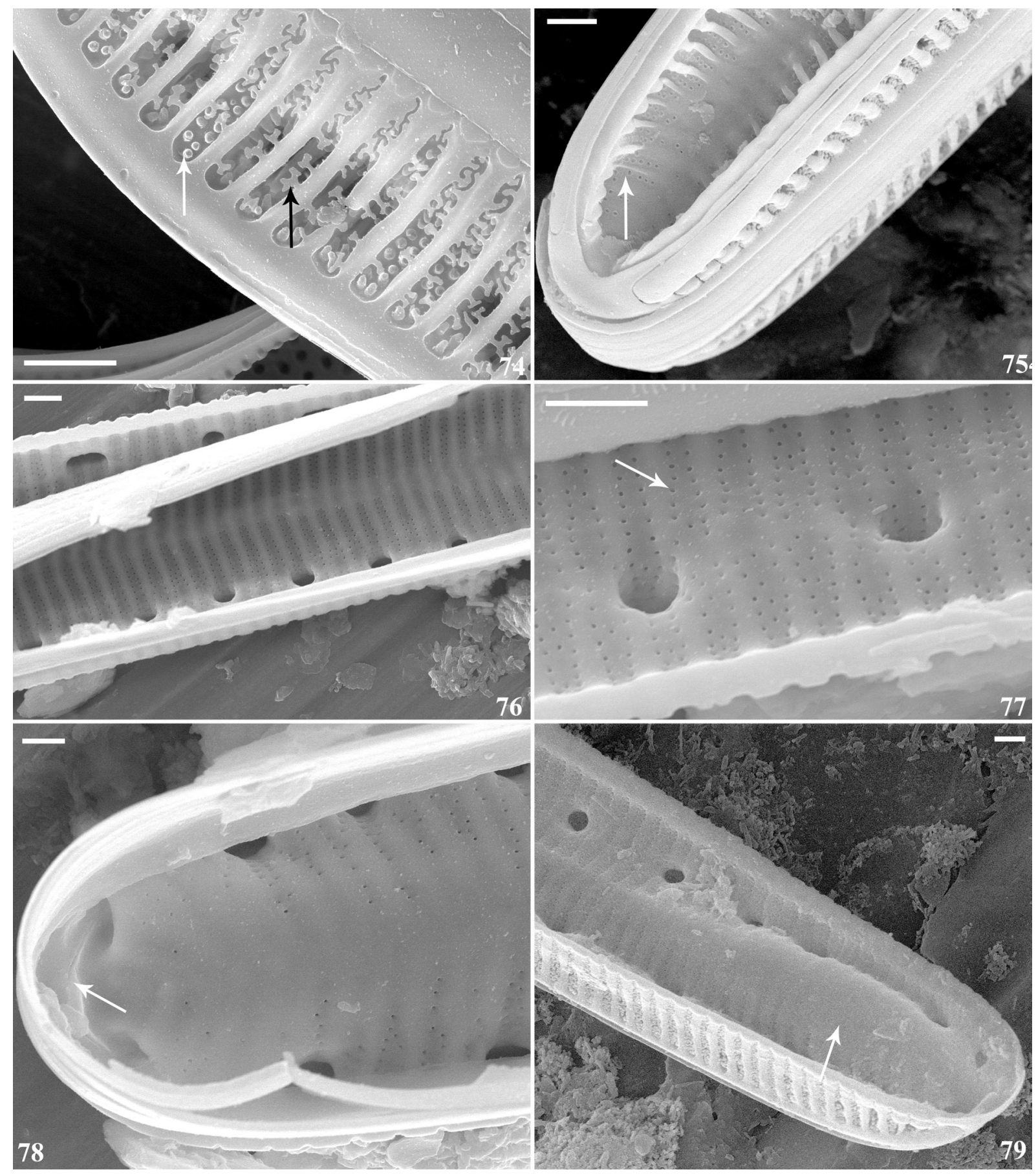

Figs 74-79. Iconella sanyatangum Liu et Kociolek sp. nov., SEM pictures: (74-75) external view of uncompleted valve; (74) girdle view of the valve apex, showing the granules (white arrow) and irregular rib sides (black arrow); (75) apex of the valve, showing the rimmed areolae (white arrow); (76-79) internal view, (76) middle of the valve, showing biseriate or multiseriate stria, (77) magnification of part of 76, showing the unoccluded areolae (white arrow), (78) apex of the valve, showing the terminal raphe endings, helictoglossa not raise, (79) apex of the valve, showing the depression of the valve ends formed a rise internally (white arrow). Scale bar $1 \mu \mathrm{m}$.

of Natural Sciences of Philadelphia 160:47-56.

EhrenBerG, C.G. (1848): Versuch einer Fauna und Flora von Britisch-Guiana.-Die Mikroskopischen Lebenformen.3: 537-544. Leipzig, J.J. Weber,

Glushchenko, A.; Kulikovskiy, M.; Kuznetsova, I.; Dorofeyuk, N. \& Kociolek, J.P. (2018): New species and combinations in the genus Eunotia Ehrenberg 1837 (Bacillariophyceae: Eunotiaceae) from waterbodies of Southeastern Asia. -Nova Hedwigia, Beiheft 147:
69-103.

Hohn, M.H. \& Hellerman, J. (1963): The taxonomy and structure of diatom populations from three Eastern North American rivers using three sampling methods. -Transactions of the American Microscopical Society 82: 250-329.

Huang, M.Z.; Yin, J.M.; Yang G.S. \& Tan, Y.H. (2012): Panisea $m o i$, a new species (Orchidaceae: Epidendroideae) from Hainan, China. -Phytotaxa 60: 13-16. 
Hustedt, F. (1933): Die Kieselalgen Deutschlands, Österreichs und der Schweiz unter Berücksichtigung der übrigen Länder Europas sowie der angrenzenden Meeresgebiete. - In: RABENHORST, L. (ed.): Kryptogamen Flora von Deutschland, Österreich und der Schweiz. -Akademische Verlagsgesellschaft m.b.h. Leipzig 7: 321-432.

Hustedt, F. (1935): Die fossile Diatomeenflora in den Ablagerungen des Tobasees auf Sumatra. -"Tropische Binnengewasser, Band VI“. - Archiv für Hydrobiologie, Supplement 14: 143-192.

Hustedt, F. (1938): Systematische und ökologische Untersuchungen über die Diatomeen-Flora von Java, Bali und Sumatra nach dem Material der Deutschen Limnologischen Sunda-Expedition. Allgemeiner Teil. I. Übersicht über das Untersuchengsmaterial und Charakteristik der Diatomeen flora der einzelnen Gebiete. -"Tropische Binnengewässer, Band VII". Archiv für Hydrobiologie, Supplement 15: 638-790.

HustedT, F. (1949): Süsswasser-Diatomeen aus dem AlbertNationalpark in Belgisch-Kongo. -Exploration du Parc National Albert, Mission H. Damas (1935-1936), -199 pp. Institut des Parcs Nationaux du Congo Belge, Bruxelles,

JAHN, R.; KusBer, W. \& COCQuYt, C. (2017): Differentiating Iconella from Surirella (Bacillariophyceae): typifying four Ehrenberg names and a preliminary checklist of the African taxa. -PhytoKeys 82: 73-112.

JianG, Z.Y.; LiU, Y.; KocioleK, J.P. \& Fan, Y.W. (2018): One new Gomphonema (Bacillariophyta) species from Yunnan Province, China. - Phytotaxa 349: 257-264.

Johansen, J. R. \& SraY, J. C. (1998): Microcostatus gen. nov., a new aerophilic diatom genus based on Navicula krasskei Hustedt. -Diatom Research 13: 93-101.

Kociolek, J.P.; Balasubramanian, K.; Blanco, S.; Coste, M.; ECTOR, L.; LIU, Y.; KuliKOVSKIY, M.; LUNDHOLM, N.; Ludwig, T.; Potapova, M.; Rimet, F.; Sabbe, K.; Sala, S.; Sar, E.; TaYlor, J.; VAn de ViJVer, B.; Wetzel, C.E.; Williams, D.M.; WitKowski, A. \& Witkowski, J. (2020): DiatomBase. - accessed at http://www.diatombase.org on 2020-02-20

KüTZING, F.T. (1844): Die Kieselschaligen. Bacillarien oder Diatomeen. - 152 pp. Nordhausen.

Lange-Bertalot, H. \& Moser, G. 1994. Brachysira. Monographie der Gattung. Wichtige Indikator Species für das Gewäser Monitoring und Naviculadicta nov. gen. - Bibliotheca Diatomologica 29: 1-212.

Lange-Bertalot, H.; BąK, M. \& Witkowski, A. (2011): Eunotia and some related genera. -Diatoms of Europe 6: $1-747$.

LEwIS, F.W. (1864): On some new and singular intermediate forms of Diatomaceae. - Proceedings of the Academy of Natural Sciences of Philadelphia 15: 336-346.

LI, J.Y. \& QI, Y.Z. (2010): Naviculaceae (I). Flora algarum cinicarum aquae dulcis. Tomus XIV. Bacillariophyta. - 177 pp., Science Press, Beijing.

Li, Y.; Cen, J.Y.; QI, Y.Z. \& Lv, S.H. (2009): Morphological features observations of Urosolenia in Chinese freshwater. -Acta Hydrobiologica Sinica 33: 565-570.

Li, Y.; SuZuki, H.; Nagumo, T.; TAnaKa, J.; Sun, Z. \& Xu, K. (2016): Microcostatus salinus sp. nov., a new benthic diatom (Bacillariophyceae) from estuarine intertidal sediments, Japan. -Phytotaxa 245 : 51-58.

Li, Y.L.; BAO, M.Y.; LiU, W.; KocioleK, J.P. \& Zhang, W. (2019). Cymbella hechiensis sp. nov., a new cymbelloid diatom species (Bacillariophyceae) from the upper tributary of Liujiang River, Guangxi Province, China. - Phytotaxa 425: 049-056.

LiU, B.; BLANCO, S. \& LAN, Q.Y. (2018a). Ultrastructure of Delicata sinensis Krammer \& Metzeltin and D. williamsii sp. nov. (Bacillariophyta) from China. - Fottea 18: 3-36.

Liu, B.; Williams, D.M. \& Ector, L. (2018b). Entomoneis triundulata sp. nov.(Bacillariophyta), a new freshwater diatom species from Dongting Lake, China. - Cryptogamie, Algologie, 39: 239-253.

Liu, B.; Blanco, S.; Ector, L.; LiU, Z.X. \& AI, J. (2019): Surirella wulingensis sp. nov. and fine structure of S. tientsinensis Skvortzov (Bacillariophytceae) from China. - Fottea 19: 151-162.

LiU, J. \& Li, S.Q. (2009): One new Draconarius species ( Araneae, Amaurobiidae) from Hainan island, China. -Acta Zootaxonomica Sinica $34: 730-732$.

LiU, J.; Wei, G.F.; Hu, R.; Zhang, C.W. \& Han, B.P. (2013): Atlas of benthic diatoms from Dongjiang watershed of Pearl River System. -108 pp. China Environment Press, Beijing.

LiU, Q.; KocioleK, J.P.; Li, B.; You, Q.M. \& Wang, Q.X. (2017): The diatom genus Neidium Pfitzer (Bacillariophycea) from Zoigê Wetland, China. -Bibliotheca Diatomologica 63: $1-120$.

Liu Q., Li J.J., NAn F.R., Feng J., Lv J.P., Xie S.L. \& KocioleK J.P. (2019a). New and interesting diatoms from Tibet: I. Description of a new species of Clipeoparvus Woodbridge et al. -Diatom Research 34:1, 33-38

Liu, Q.; Glushchenko, A.; Kulikovskiy, M.; Maltsev, Y. \& Kociolek, J.P. (2019b). New Hannaea Patrick (Fragilariaceae, Bacillariophyta) species from Asia, with comments on the biogeography of the genus. -Cryptogamie, Algologie 40: 41-61.

LiU, Y.; KocioleK, J.P. \& Fan, Y.W. (2016): Urosolenia and Acanthoceras species from Hainan Province, China. - Phytotaxa 244: 161-173.

Liu, Y.; Kociolek, J.P.; Glushchenko, A.; KulikovskiY, M. \& FAN, Y.W. (2018a): A new genus of Eunotiales (Bacillariophyta, Bacillariophyceae: Peroniaceae), Sinoperionia, from Southeast Asia, exhibiting remarkable phenotypic plasticity with regard to the raphe system. - Phycologia 57: 147-158.

LiU, Y.; KocioleK, J.P.; WANG, Q.X. \& FAN, Y.W. (2014a): A new species of Neidium (Bacillariophyceae) and a checklist of the genus from China. -Diatom Research 29: $165-173$.

LiU, Y.; KocioleK, J.P.; Wang, Q.X. \& Fan, Y.W. (2018b): Diatom genus Pinnularia from Great Xing'an Mountains, China. -Bibliotheca Diatomologica 65: 1-298.

Liu, Y.; KocioleK, J.P.; Wang, Q.X.; XIANG, T. \& Fan, Y.W. (2014b): Two new species of monoraphid diatom (Bacillariophyceae) from South of China. - Phytotaxa 188: 31-37.

LiU, Y.; KocioleK, J.P.; LiU, Q.; Tan, X. \& Fan, Y.W. (2020a). A new aerophilic Neidium Pfister (Neidiaceae, Bacillariophyta) species from Guangxi Zhuang Autonomous Region, China. - Phytotaxa 432: 171-180.

LiU, Y.; KocioleK, J.P.; Lu, X.X. \& FAN, Y.W. (2020b). A new Sellaphora Mereschkowsky species (Bacillariophyceae) from Hainan Island, China, with comments on the current state of the taxonomy and morphology of the genus. -Diatom Research 35: 85-98.

LiU, Y.; KocioleK, J.P.; Lu, X.X. \& FAN, Y.W. (2020c). Valve ultrastructure of two species of the diatom genus Gomphonema Ehrenberg (Bacillariophyta) from Yunnan 
Province, China. - Fottea, Olomouc 20: 25-35.

Luo, F.; You, Q.M. \& WANG, Q.X. (2018): A new species of Genkalia (Baicllariophyta) from mountain lakes within the Sichuan Province of China. -Phytotaxa 372: 236-242.

Metzeltin, D. \& Lange-Bertalot, H. (1998): Tropical diatoms of South America I: About 700 predominantly rarely known or new taxa representative of the neotropical flora. -Iconographia Diatomologica 5: 1-695.

Metzeltin, D. \& Lange-Bertalot, H. (2002): Diatoms from the "Island Continent" Madagascar. -Iconographia Diatomologica 11: 1-286

Metzeltin, D. \& LANGe-Bertalot, H. (2007): Tropical diatoms of South America II. Special remarks on biogeography disjunction. -Iconographia Diatomologica 18: 1-877.

Myer, N.; Mittermeier, R.A.; Mittermeier, C.G.; FonseCA, G.A.B. \& Kent, J. (2000): Biodiversity hotspots for conservation priorities. -Nature 403: 853-858.

Patrick, R.M. \& ReImer, C.W. (1966): The Diatoms of the United States exclusive of Alaska and Hawaii. Volume 1. Fragilariaceae, Eunotoniaceae, Achnanthaceae, Naviculaceae. -Monographs of the Academy of Natural Sciences of Philadelphia 13:1-688.

PATrick, R.M. (1940): Some new diatoms from Brazil. Notulae Naturae (Academy of Natural Sciences of Philadelphia) 59: 1-7.

Pavlov, A. \& Levkov, Z. (2013): Diversity and distribution of taxa in the genus Eunotia Ehrenberg (Bacillariophyta) in Macedonia. -Phytotaxa 86: 1-117.

QI, Y.Z. \& LI, J.Y. (2004): Araphidales \& Raphidionales. -Flora algarum sinicarum aquae dulcis (Tomus X): Bacillariophyta. -161 pp., Science Press, Beijing.

QI, Y.Z. (1995): Centricae. - Flora algarum sinicarum aquae dulcis (Tomus IV): Bacillariophyta. - 104 pp., Science Press, Beijing.

Round, F.E.; Crawford, R.M. \& Mann, D.G. (1990): The diatoms. Biology and morphology of the genera. -747 pp., Cambridge University Press, Cambridge.

Ruck, E.C.; Nakov, T.; Alverson, A.J. \& Theriot, E.C. (2016). Phylogeny, ecology, morphological evolution, and reclassification of the diatom orders Surirellales and Rhopalodiales. - Molecular Phylogenetics and Evolution 103: 155-171.

Rumrich, U.; Lange-Bertalot, H. \& Rumrich, M. (2000): Diatomeen der Aden. Von Venezuela bis Patagonien (Feuerland). -Iconographia Diatomologica 9: 1-649.

Schmidt, A. (1911). Atlas der Diatomaceen-kunde. -Leipzig. O.R. Reisland Series VI(Heft 69):pls. 273-276.

Schmidt, A. (1934): Atlas der Diatomaceen-kunde, Series VIII, Heft 97-98. - pls. 385-392, O.R. Reisland, Leipzig.

SHI, Z.X. (2004): Gomphonemaceae. -Flora algarum sinicarum aquae dulcis. Tomus XII, Bacillariophyta.- 147 pp., Science Press, Beijing.

SHI, Z.X. (2013): Cymbellaceae. - Flora algarum sinicarum aquae dulcis. Tomus XVI, Bacillariophyta. -217 pp., Science Press, Beijing.

Simonsen, R. (1987): Atlas and Catalogue of the Diatom Types of Friedrich Hustedt. - 2: 1-395 pls. J. Cramer, Berlin \& Stuttgart.

Stanek-Tarkowska, J.; Wetzel, C.E.; Noga, T. \& Ector, L. (2016): Study of the type material of Navicula egregia Hustedt and descriptions of two new aeial Microcostatus (Bacillariophyta) species from Central Europe. -Phytotaxa 280: 163-172.

TAYlor, J.C.; LeVANETS, A.; Blanco, S. \& Ector, L. (2010):
Microcostatus schoemanii sp.nov., M. cholnokyi sp. nov. and $M$. angloensis sp. nov. three new terrestrial diatoms (Bacillariophyceae) from South Africa. -Phycological Research 58: 177-187.

Torgan, L.C. \& Becker, V. (1997): Eunotia densistriata sp.nov.: a subaerial diatom from Southern Brazil. Diatom Research 12: 115-124.

VAn de Vijver, B.; Ector, L.; HaAn, M. \& Zidarova, R. (2010): The genus Microcostatus in the Antarctic Region. -Diatom Research 25: 417-429.

Van de Vijver, B.; Kopalová, K.; Zidarova, R. \& Cox, E.J. (2013): New and interesting small-celled naviculoid diatoms (Bacillariophyta) from the Maritime Antarctic Region.- Nova Hedwigia 97: 189-208.

Vouilloud, A.A.; SAla, S.E.; NúÑEZ-Avellaneda, M.; Montoya-Moreno, Y. \& DuQue, S.R. (2014): Brachysira (Naviculales, Bacillariophyceae) in lowland waters from Colombia. - Diatom Research 29: 147-163.

Vyverman, W.; Sabbe, K.; Mann, D.G.; Kilroy, C.; Vyverman, R.; Vanhoutte, K. \& Hodgson, D. (1998): Eunophora gen. nov. (Bacillariophyta) from Tasmania and New Zealand: description and comparison with Eunotia and amphoroid diatoms. -European Journal of Phycology 33: 95-111.

Williams, D.M. \& ReID, G. (2006a): Amphorotia nov. gen., a new genus in the family Eunotiaceae (Bacillariophyceae), based on Eunotia clevei Grunow in Cleve \& Grunow. - Diatom Monographs 6: 1-153.

Williams, D.M. \& ReID, G. (2006b): Fossils and the tropics, the Eunotiaceae (Bacillariophyta) expanded: A new genus for the Upper Eocene fossil diatom Eunotia reedii and the recent tropical marine diatom Amphora reichardtii. -European Journal of Phycology 41: 147-154.

YANG, S.Q.; Zhang, W.; Blanco, S.; JÜtTneR, I. \& Wu, Z.X. (2019): Delicata chongqingensis sp. nov., a new cymbelloid diatom species (Bacillariophyceae) from Daning River, Chongqing, China. -Phytotaxa 393: 57-66.

You, Q.M.; KocioleK, J.P.; CAI, M.J.; Lowe, R.L.; LiU, Y. \& WANG, Q.X. (2017): Morphology and ultrastructure of Sellaphora constrictum sp. nov. (Bacillariophyta), a new diatom from southern China. -Phytotaxa 327 : 261-268.

You, Q.M.; CaO, Y.; Yu, P.; KocioleK, J.P.; Zhang, L.X.; Wu, B.; Lowe, R. \& WANG Q.X. (2019a): Three new subaerial Achnanthidium (Bacillariophyta) species from a karst landform in the Guizhou Province, China. -Fottea, Olomouc 19: 138-150.

You, Q.M.; Yu, P.; Kociolek, J.P.; Wang, Y.L.; LuO, F.; Lowe, R. \& WANG, Q.X. (2019b): A new species of Achnanthes (Bacillariophytceae) from a freshwater habitat in a karst landform from south-central China. -Phycological Research 67: 303-310.

Yu, P.; KocioleK, J. P.; You, Q.M. \& WANG, Q.X. (2018): Achnanthidium longissimum sp. nov. (Bacillariophyta), a new diatom species from Jiuzhai Valley, Southwestern China. - Diatom Research 33: 339-348.

Yu, P.; You, Q.M.; Kociolek, J. P. \& WANG, Q.X. (2019): Three new freshwater species of the genus Achnanthidium (Bacillariophyta, Achnanthidiaceae) from Taiping Lake, China. - Fottea 19: 33-49.

ZhANG, Z. \& CAI, S.X. (1988): A New Variety of Gomphonema turris Ehr. - Journal of Graduate School of Science Academy in China 26: 408.

Zhang, Z. \& QI, Y.Z. (1993): A new species and some new records of the genus Eunotia Ehr. From China. -Journal 
of Jinan University (Natural Science) 14: 80-83.

ZHANG, Z. \& QI, Y.Z. (1994): Some new taxa and records of the order Araphidinales from China. - Journal of Jinan University (Natural Science) 15: 125-129.

Zhang, W.; Shang, G.X.; Kociolek, J.P.; WANG, L.Q. \& ZHANG, R.L. (2018a): Oricymba rhynchoceplhala $s p$. nov., a new cymbelloid diatom (Bacillariophyceae) from Xianju National Park in Zhejiang Province, China. -Phytotaxa 340: 063-070.

Zhang, W.; JÜttner, I.; Cox, E.J.; Chen, Q. \& Tan, H.X. (2018b): Cymbella liyangensis sp. nov., a new cymbelloid species (Baciilariophyceae) from streams in North Tianmu Mountain, Jiangsu province, China. -Phytotaxa 348: 014-022.
Zhang, W.; Wang, T.; LeVkov, Z.; JÜtTNER, I.; ECTOR, L. \& ZHou Q.C. (2019): Halamphora daochengsis sp. nov., a new freshwater diatom species (Bacillariophyceae) from a small mountain lake, Sichuan Province, China. -Phytotaxa 404: 012-022.

Zнао, E.M. (1997): A new species of Rhabdophis (Serpentes: Colubridae) from Hainan Island, China. -Asiatic Herpetological Research 7:166-169.

ZhaO, Q.; Sun, J.; JiAnG, J.B. \& QiU, J.P. (2013): Four new species of genus Amynthas (Oligochaeta, Megascolecidae) from Hainan Island, China. - Journal of Natural History 47:33-34, 2175-2192.

(C) Czech Phycological Society (2021)

Received April 25, 2020

Accepted September 22, 2020 